\title{
Crime Stories: Posnerian Pragmatism, RaWlsian PuRe Procedural Justice, AND the Fictional Problem
}

\author{
JOHN R MORSs
}

[There are many different ways in which law and truth may be said to be related. It is perhaps in the criminal trial that connections between them are of most significance. An orthodox way of describing a criminal trial is that the criminal procedure is seeking to establish the truth concerning some past event, and that success of the procedure is measured by how close its outcome converges with that truth. Criminal justice presents the community with challenging dilemmas in this regard, such as those arising from the notion of double jeopardy. This paper discusses the Rawlsian notions of 'imperfect', 'perfect' and 'pure' procedural justice, and suggests against Rawls that it is pure procedural justice that best represents what we want from a criminal justice system. Good procedure makes good criminal law. A comparison is made with the writings of Habermas and Posner, and given that pure procedural justice eschews transcendental truths, some brief comments are made on the convergence of that position with the realm of the fictional.]

\footnotetext{
"Lecturer; Associate Head (Research and Program Development), School of Law, Deakin University. An earlier version of this paper was presented to the Annual Conference, Australasian Law Teachers' Association, Darwin, July 2004 and I am appreciative of the encouragement of ALTA colleagues.
} 


\section{INTRODUCTION}

There are many different ways in which law and truth may be said to be related, but it is in the criminal trial that putative connections between them are asserted with most heat and with most consequence. Criminal justice presents the community with challenging dilemmas such as those arising from the notion of double jeop$\operatorname{ardy}^{1}$ and from the practice of eliciting confessions by means of 'sting' operations. An orthodox way of describing a criminal trial is that the criminal procedure is seeking to establish the truth concerning some past event, and that success of the procedure is measured by how close its outcome converges with that historical truth. While the range of the aspects of an event about which truth is sought may be highly circumscribed - perhaps limited to 'guilt' versus 'innocence' of an accused person - the central place of truth-finding seems secure both practically and conceptually.

The orthodox analysis sketched above is consistent with John Rawls' description of the criminal trial as exemplifying 'imperfect procedural justice. ${ }^{2}$ In Rawls' words, 'The desired outcome is that the defendant should be declared guilty if and only if he has committed the offense with which he is charged.' For Rawls, the correct following of the procedure may sometimes lead to 'the wrong outcome' which arises 'from a fortuitous combination of circumstances which defeats the purpose of the legal rules. ${ }^{3}$ Most significantly, 'while there is an independent criterion for the correct outcome, there is no feasible procedure which is sure to lead to it.'

Rawls contrasts imperfect procedural justice with (on the one hand) 'perfect procedural justice' and (on the other) 'pure procedural justice.' The former is exemplified by one's cutting of a cake in equal portions, with one's own slice to be chosen last. In this kind of circumstance, Rawls argues, 'there is an independent standard for deciding which outcome is just and a procedure guaranteed to lead to it.' Such circumstances are in terms of practical significance (for example in the legal context), 'rare, if not impossible. ${ }^{4}$ The latter alternative - pure procedural justice - is characterised by the absence of an independent criterion for the right result, so that justice is manifested (if at all) in the procedure itself. Rawls' example of pure procedural justice is a fair and transparent system of betting, where punters voluntarily participate in a wager with known probabilities of outcome.

\footnotetext{
${ }^{1}$ Charles Parkinson, 'Double Jeopardy Reform: The New Evidence Exception for Acquittals' (2003) 26 University of New South Wales Law Journal 603.

${ }^{2}$ John Rawls, A Theory of Justice (1973) 85.

${ }^{3}$ Ibid 86.

${ }^{4}$ Ibid 85. Also see Tom Campbell, Justice ( $2^{\text {nd }}$ ed, 2001) 98.
} 
What I wish to argue is that the criminal trial is in fact, in Rawls' terminology, an arena for pure procedural justice: a situation in which procedural fairness is all there is. It is not, that is to say, that the independent assessment of the truth of a verdict is a practical difficulty, even one of extreme proportions (as Rawls would not hesitate to concede). It is rather that such independent assessment is an impossibility. I will therefore wish to suggest (against Rawls) that the comments he makes about pure procedural justice apply to the criminal trial. My working hypothesis is that there is no transcendental position from which to evaluate the outcome of a criminal trial the outcome is correct if the procedure is correct. Pure procedural justice is as good as it gets.

The attempt will be made to draw connections with the position of Habermas ${ }^{5}$ for whom rule of law in general is a matter of procedural justice, not a matter of outcomes as such. Indeed the re-reading of Rawls' pure procedural justice is suggested by the writings of Habermas. A focus on outcomes is for Habermas characteristic of morality-based decisions; procedure, closely interrelated with democratic legitimacy itself, is the stuff of justice. One purpose of this paper is thus to examine in an exploratory manner the implications of Habermas' position for criminal justice, not an area of law that Habermas has discussed in detail. More generally, in making these claims it might be said that a pragmatic approach to truth has been adopted. It is therefore of considerable relevance to examine the recent writings of Richard Posner $^{6}$ on the pragmatic approach to legal decision-making. Posner's illustrations tend to be drawn from the civil law of torts, of contract and of (US) constitutional interpretation so that examination of criminal law is an important test for his claims. It will be argued that Rawlsian 'pure procedural justice' when treated (contra Rawls) as applicable to criminal procedure, converges usefully with Posnerian pragmatism.

Apart from exegesis, concrete claims are being advanced here. The outcome of a criminal trial is the 'right answer' as long as the procedure has been correct. Procedures may be changed and there is probably little sense to a notion of 'perfect' adherence to criminal procedure (for example in relation to procedures on hearsay evidence). Indeterminacy in relation to 'guilt' or 'innocence' is not to be substituted by a spurious determinacy of process. But the former is to be taken seriously, as a matter of principle not of mere convenience. As with the celebrated Azaria Chamberlain case in Australia's Northern Territory some years ago, it is entirely proper for journalists and members of the general public (or lawyers off-duty) to seek other kinds of truth about real events, but it is the task of the criminal process to establish its own, procedural truth - the truth of outcome as defined by Rawls as 'pure procedural justice.'

Finally, there are some significant ways in which this approach to criminal justice converges not only with the methodological claims of Posner and of Habermas but

\footnotetext{
${ }^{5}$ Jurgen Habermas, Between Facts and Norms: Contributions to a Discourse Theory of Law and Democ$\operatorname{racy}(1996)$.

${ }^{6}$ Richard Posner, Law, Pragmatism and Democracy (2003).
} 
also with what may appear a different realm altogether - the domain of fiction. These connections will be explored in the final section.

\section{Re-Writing RaWLS}

As noted above, Rawls has contrasted the form of justice he considers appropriate to the criminal process ('imperfect procedural justice') with what he calls 'pure procedural justice.' A fair system of betting illustrates pure procedural justice. As long as the procedure is agreed to, tossing a coin or drawing straws generates a just outcome in a manner that cannot be validated or invalidated independently. Thus for Rawls, the distinction between imperfect procedural justice (eg the criminal trial) and pure procedural justice (eg fair gambling) is that in the former there is an independent criterion by which to judge the outcome - albeit a criterion which cannot be perfectly articulated to a procedure. It is argued here (against Rawls) that the description Rawls gives of pure procedural justice can be applied aptly to criminal justice as properly understood.

Thus it might be said (a) that it is by recourse to a 'public system of rules' that the legitimacy of claims are established; (b) that 'the correctness of the distribution is founded on the justice of the scheme of cooperation from which it arises'; and (c) that 'a distribution [that is, an outcome] cannot be judged in isolation from the system of which it is the outcome or from what individuals have done in good faith in the light of established expectations. ${ }^{, 7}$ All of these comments, it is argued, accurately and helpfully apply to criminal justice. The procedures which are its core are essentially social practices, as all three statements emphasise. They constitute a scheme of cooperation, in which not only the official and legal representatives but also the accused person, the public and the wider community may be said to be collaborating. 'Established expectations' sums up well the ongoing effectiveness of the procedures of criminal justice.

It may be observed that comment (b) above refers to the 'justice' of the scheme of cooperation. This is no appeal to metaphysics, for recall that Rawls' own reference in this phrase is to the situation of fair betting. The justice, such as it is, is immanent in the process: it is a fair process, not a process that reminds us of an ideal of justice. In applying Rawls' comments to the criminal justice situation then, as essayed here, no transcendental sense of justice need be superadded. Of course, Rawls' own take on criminal justice involves an appeal to the kind of liberal world-view that he posits in general, with its presumptions of equality as if derived in the 'original position.' But in his brief account of pure procedural justice Rawls has given us an escape-hatch from the paraphernalia of the original position and the 'veil of ignorance.' According to the present re-writing of Rawls, the community can inspect the

${ }^{7}$ Rawls, above n 2, 88. To emphasise, Rawls' words are intended by him to describe pure procedural justice but not to be applicable to the criminal justice system. 
legal system with its eyes open, fully aware of actual inequities of distribution and of opportunity, and can adjust the system as it sees fit. There is no necessity to construct the legal fiction (as it were) of the original position with its deliberative hunch-making about least risky future scenarios. Among other problematic aspects, the original position raises some similar issues to the entrenching of constitutions ${ }^{8}$ for in both cases, a kind of legitimacy is asserted for the constraining of future generations, albeit the constraint in Rawls' case is a conceptual rather than a statutory one. Conceptual entrenchment (or other kinds of foundationalism it might be said $^{9}$ ) plays no part in the notion of pure procedural justice. ${ }^{10}$ All is up for grabs at least in principle. This is not to say that the monitoring and reform of law is efficient or even satisfactory, but that the barriers to this are practical and thus contingent ones rather than necessary ones.

Rawls' notion of 'quasi-pure procedural justice' should be noted at this point. 'Quasi-pure procedural justice' refers to a characteristic of legislative (not courtroom) process. Rawls acknowledges that considerable indeterminacy is involved in legislation, which despite this (intrinsic) open-endedness can still be said to be just. The justice is of a procedural nature, such that 'laws and policies are just provided that ... the legislature, in ways authorized by a just constitution, has in fact enacted them, ${ }^{11}$ but the level of procedure is institutional not judicial. It might be thought that in noting this 'quasi-pure' procedural character of legislation Rawls is opening the way for a procedural approach to criminal justice, but Rawls' reference to a 'just constitution' is a significant qualification to the quasi-pure procedural form of justice even at the legislative level, and there is no indication of Rawls doubting his categorization of criminal justice as imperfect (rather than pure) procedural justice.

\section{Habermas and the Legitimation Process}

The third cited phrase from Rawls, above, that 'a distribution cannot be judged in isolation from the system of which it is the outcome,' directs us towards Jurgen Habermas. Habermas has been concerned throughout his writings with institutional structure in relation to societal communication. Systemic thinking, such as that of the sociologist Luhmann, underpins much of Habermas' analysis of social mediation and civil society although Habermas takes care to avoid a holistic or totalistic analysis of society: ${ }^{12}$ 'law is not a narcissistically self-enclosed system. ${ }^{13}$ Some-

\footnotetext{
${ }^{8}$ Jeremy Waldron, Law and Disagreement (1999) 259; see also Jon Elster, Ulysses Unbound (2000) 92.

${ }^{9}$ Richard Rorty, 'Human Rights, Rationality, and Sentimentality' in Obrad Savic (ed), The Politics of Human Rights (1999) 67.

${ }^{10}$ Rawls' third kind of justice, the perfect procedural justice of cutting up a cake, itself relies on what might be called conceptual entrenchment (of orthodox western logic etc), but of course Rawls has not suggested that this kind of justice has any practical (and at the same time significant) relevance to law.

${ }^{11}$ Rawls, above n 2201.

${ }^{12}$ Kenneth Baynes, 'Democracy and the Rechtsstaat: Habermas's Faktizitat und Geltung [Between Facts and Norms]' in Stephen White (ed) The Cambridge Companion to Habermas (1995) 201, 214.
} 
what hard to pin down or to encapsulate, partly because of his insistence on the institutional complexity of modern society, Habermas has nevertheless ensured that certain traps are avoided. While strongly influenced by Marxist traditions of analysis, with its concern with the dynamics of conflicting interests and of conflicting knowledge, Habermas avoids the dogmatism and partisanship of Marxist scholarship. ${ }^{14} \mathrm{He}$ also eschews other forms of dogmatism including the appeal to idealist or narrowly positivistic traditions.

In turning his attention to law, Habermas states that a discourse theory of law 'conceives constitutional democracy as institutionalizing ... the procedures and communicative presuppositions for a discursive opinion- and will-formation that in turn makes possible legitimate lawmaking. ${ }^{15}$ Habermas describes Rawls' project as being located in a 'social-contract tradition of rational natural law' ${ }^{16}$ which overlooks more than a century of social scientific critique of law. Rawls has failed in his attempt to bridge the chasm between 'ideal theoretical demands and social facts. ${ }^{17}$

Habermas argues in general that legal procedure generates just outcomes if properly located within a democratic system. Thus

$[\mathrm{P}]$ rocedural norms regulate participation and the distribution of roles in discursive processes of opinion- and will-formation ... discourses for making and applying law can be socially expected in specific places at specific times.

Habermas does not make specific comments on criminal law, but in relation to courtroom process generally he observes:

The legal procedure ... demand[s] timely, unambiguous, and binding decisions. This is because legal procedures allow one to monitor adherence to procedural norms from an observer's perspective. Thus the legal code gives a socially binding character to procedurally correct results; it supplies a procedural rationality of its own that compensates for the weaknesses of its complement, the procedural rationality inherent in the process of argumentation. Legal institutionalization thus has the sense of grafting a quasi-pure procedural justice, as Rawls puts it, onto discourses and their imperfect procedural rationality. In this way the logic of argumentation is not frozen but put to work for the production of reasonable decisions having the force of law. ${ }^{19}$

\footnotetext{
${ }^{13}$ Habermas, above n 5, 461

${ }^{14}$ James Marsh, Unjust Legality: A Critique of Habermas's Philosophy of Law (2001). Also see Tom Campbell's comparison of Habermas with Adam Smith, Campbell, above n 4, 234.

${ }^{15}$ Habermas, above n 5, 437.

${ }^{16}$ Ibid 56.

${ }^{17}$ Ibid 64.

${ }^{18}$ Ibid 178 .

${ }^{19}$ Ibid 178-9.
} 
Habermas' reference is to Rawls' quasi-pure procedural justice (discussed above) rather than to ('actual'?) pure procedural justice, as is being proposed here. Certainly Rawls' sense of institutional legitimation of legislation converges with Habermas.' But compared to Rawls, Habermas seems more willing to press the relevance of (some variety of) pure procedural justice to the courtroom and not merely to the parliament. And in a remark that might have been made by Posner, Habermas comments that 'only the reformist path of trial and error remains both practically available and morally reasonable. ${ }^{, 20}$

\section{Posner's Pragmatism}

Richard Posner has explored a pragmatic approach to law in many writings. Thus in The Problems of Jurisprudence he emphasizes a preference for 'shaping the future' rather than 'maintaining continuity with the past. ${ }^{21}$ Elsewhere Posner has observed: 'Ever since Socrates there have been influential thinkers who were skeptical about the capacity of legal reasoning to deliver something that could reasonably be called "truth.",22

It is in Posner's more recent Law, Pragmatism and Democracy that the approach is systematized, defended, and compared more expressly with other approaches. It has been remarkable for some while that Posner's approach has been the most rigorously materialist of any contemporary jurisprudence. Posner's focus on an interestbased analysis of law has in this sense, if paradoxically, displaced Critical Legal Studies as the (albeit distant) heir to a Marxist approach to law. Consistent with his materialist approach, Posner now urges that a thoroughgoing pragmatism be implemented. Legal pragmatism for Posner is above all a description of the current practice of societies like the USA: it is not in itself the normatively best system tout court. $^{23}$ Legal pragmatism is not the same as consequentialism although it is closer to utilitarian positions than to deontological ones. It values reasonableness and systematicity, but not above everything, and its most central characteristic is its resistance to dogmatism.

Posner is clear that the role of philosophy in the courtroom is very limited, so that pragmatism as technical philosophy is not of central concern to him. Contemporary pragmatic philosophies such as those of Habermas and Rorty are no more relevant in a direct sense than those of Pierce or James. ${ }^{24}$ Posner is interested in what pragmatism does, not what it says. Somewhat like Stanley Fish, who has emphasized that law involves the practical rather than the theoretical ('Throw strikes and keep

\footnotetext{
${ }^{20}$ Ibid 57.

${ }^{21}$ Richard Posner, The Problems of Jurisprudence (1990) 28.

${ }^{22}$ Richard Posner, Overcoming Law (1995) 2.

${ }^{23}$ Posner, above n 6, 94.

${ }^{24}$ Ibid 41.
} 
'em off the bases, ${ }^{25}$ ), Posner deflates the pretensions of his profession. According to Posner, the judge "should try to make the decision that is reasonable in the circumstances, all things considered. ${ }^{26}$ Dworkinian principles of integrity are rejected. Posner continues, 'Difficult legal questions tend not to have "right" answers in a sense that Plato would recognize: ${ }^{27}$ instead, law is more Aristotelian, friendly to persuasion, to rhetoric, and to the empirical. As Posner comments in discussing Dewey, the pragmatic approach asserts and deals with a world in which 'truth' is 'always just out of reach. ${ }^{28}$ Pragmatism is inevitably (but pragmatically ${ }^{29}$ ) Darwinian, says Posner, so that truth can never be more than empirical and practical, a working solution to an ecological problem rather than a connection to a higher plane.

Posner outlines a series of characteristics of a legal pragmatism, ${ }^{30}$ many of which are of general if not of specific relevance to the present discussion. Thus for adjudication, 'the ultimate criterion is reasonableness.' Following past decisions is 'a (qualified) necessity rather than ... an ethical duty' but at the same time 'there are bound to be formalist pockets in a pragmatic system of adjudication.' Later Posner comments on differences between US and (Continental) European legal systems, noting that the higher degree of specialization in the latter gives rise to the sharing of 'the premises of analysis and decision' by those specialists, 'enabling them to derive conclusions by logical processes. ${ }^{31}$ Posner's examples of specialized courts in Europe are labour courts and criminal courts, so that Posner's approach to criminal justice may tentatively be extrapolated from these comments. While Posner does not discuss procedure as such, as constituting a pragmatic methodology for decision-making, it seems entirely consistent with his approach that procedure take that role at least insofar as this displaces a transcendental truth-seeking.

There are definite convergences with Habermas, as suggested by Habermas' cited words above ('the logic of argumentation is not frozen but put to work for the production of reasonable decisions having the force of law'). ${ }^{32}$ Posner concedes that 'pragmatism has no soul; it has no roots in concepts of justice or natural law; it has nothing to set against public opinion. ${ }^{33}$ Such self-deprecation may be more than a little rhetorical but the point is made. (Criminal) law surely cannot be about 'did he really do it?'

\footnotetext{
${ }^{25}$ Stanley Fish, 'Dennis Martinez and the Uses of Theory', in Doing What Comes Naturally (1989) 372; see also John R Morss, 'Who's Afraid of the Big Bad Fish? Rethinking What the Law Wishes to Have' (2003) 27 Melbourne University Law Review 199.

${ }^{26}$ Posner, above n 6, 73 .

${ }^{27}$ Ibid 83.

${ }^{28}$ Ibid 103 .

${ }^{29}$ Presumably, just like a Darwinian species, only until something better (more successful at doing the same things) comes along - which could be very soon, or not, or never.

${ }^{30}$ Posner, above n 6, 59-60.

${ }^{31}$ Ibid 95.

${ }^{32}$ Although it must also be noted that Posner has 'very little sympathy' for most of Habermas' work, Ibid 27.

${ }^{33}$ Ibid 94.
} 


\section{FICTION}

It may therefore be suggested that criminal justice operates without external validation - its 'truth' must be defined in its own terms. Proper procedure is the only route to proper outcomes. It would seem that bringing the criminal trial into the sphere of Rawlsian pure procedural justice in this way at the same time brings it much closer to the fictional realm in which, likewise, validity is derived from coherence rather than from transcendence. The link from Posner to the role of fiction is of course made easy by his own writings on those connections ${ }^{34}$ although Posner's lines of thought on the connections between law and literature have gone in other directions. Clearly, in The Hound of the Baskervilles, there is no serious point to the question 'Yes but did Stapleton really do it?' There is no outside reference point. ${ }^{35}$ It might be suggested then that the same attitude is required in the real-world criminal trial: a decision is required in internal terms.

The step from procedure to internal coherence as in fiction needs more scrutiny. The relationship may be at best an analogy. However the relevance of the comparison is supported by a consideration of the fictional problem in the teaching of law. Clearly, the fact scenario of any real case may be appropriated by a lecturer in criminal procedure or in evidence in an Australian Law School, as a teaching or an assessment instrument: varying some facts or introducing new ones, rendering the real hypothetical. This problem-based method of teaching and of assessing is well established and there is every reason to think it effective. Such hypothetical problems may of course be derived from the combination of a multitude of real cases, rather than derived directly from one, or they may be invented by the imaginative law teacher on the basis of theoretical or methodological issues. The epistemological category seems the same: we are clearly describing 'fiction.' As such, and whether or not the Law School teacher indulges him- or herself by inventing amusing names for the major characters in the problem (a distressingly common failing), the law-teaching problem is of the same genre as The Hound of the Baskervilles, Hamlet, and other crime stories. The hypothetical (pedagogical) legal problem may therefore be said to be identical with a real-life legal problem not only in form, but also in epistemological status. Legal decision-making involves problem-solving in circumstances where there is no (external) right answer. The teaching problem, where grades are at stake, is on all fours with the real-life problem, where freedom is at stake. This may be welcome news to the law teacher because it validates her or

\footnotetext{
${ }^{34}$ Richard Posner, Law and Literature (rev ed, 1998); also in Posner, above n 22, 491. On law and literature, see Richard Edney, 'Literary Concepts and the Plea in Mitigation' (2004) 9 Deakin Law Review 183.

${ }^{35}$ The question can certainly be asked as to whether Stapleton's guilt is convincing in terms of the content of the tale; his questionable prospects of obtaining his hound-assisted Baskerville inheritance presents a 'formidable difficulty': Arthur Conan Doyle, The Hound of the Baskervilles (Penguin ed 1982) 173. But this difficulty is still within the story-world.
} 
his everyday use of hypothetical problems as simulation - working through such problems really does provide perfect training for the real thing.

An example may be taken from the area of juvenile justice to further illustrate the possible interrelations of the fictional and the factual in legal discourse. The example arises from the inclusion of fictional examples of juvenile crime in discussions of the forensic role of demeanor. Specifically the claim has been made ${ }^{36}$ that apparent remorselessness in young offenders is to be interpreted entirely differently from remorselessness in adult offenders because of supposed developmental effects. Duncan's argument brings together real examples of teenage murderers, and fictional examples.

Given the analysis above, in which the orthodox distinction between fictional and factual is problematised, Duncan's method should not be disdained without some further consideration. The major difficulties with Duncan's claims concern and arise from the status of supposedly scientific findings on human development, viz findings from developmental psychology on the characteristics of the human adolescent. For Duncan, such scientific claims provide legitimacy for both kinds of examples. That is, both factual and fictional examples of adolescent human conduct illustrate and/or reflect the underlying truths being established by a scientific psychology. Thus Duncan's amalgamation of factual and fictional examples does not serve to challenge the distinction in any serious way - rather, it serves to subordinate both (legal) fact and fiction to scientific fact. Quite explicitly, Duncan portrays the purpose of a criminal trial (of a young person in this case) as being to 'reveal' 'the real child. ${ }^{, 37}$ A sense of truth of a transcendental kind (relative to the mundane outcome of the legal procedure) is presupposed, not greatly different from the independent criterion in Rawls' perfect procedural justice. What is suggested here in contrast to this, is that as with the analysis above, the better account is one that foregrounds pure rather than perfect procedural justice.

\footnotetext{
${ }^{36}$ Martha Grace Duncan, “'So Young and So Untender”: Remorseless Children and the Expectations of the Law' (2002) 102 Columbia Law Review 1469; John R Morss, 'Rosencrantz and Guildenstern are Nevertheless Dead: The Hypothetical Adolescence of Prince Hamlet and the Contested Remorselessness of Young Offenders' (forthcoming).

${ }^{37}$ Duncan, above n 36, 1526.
} 


\section{IMPLICATIONS AND QUERIES}

As Posner has commented (in a relevant discussion of Camus' L'Etranger), ' $[\mathrm{t}] \mathrm{he}$ law has its own purposes, which are not those of psychology. ${ }^{38}$ The same attitude, it might be said, is required in the real-world criminal trial. Instructions to a jury might need some careful re-consideration if this suggestion were to be adopted. However the proposal is not entirely far-fetched. There is a present understanding that in some situations even though a jury may be convinced of a person's guilt they recognize that there just is not enough evidence to support a conviction. Juries will often, quite properly, be correspondingly directed in that the operational meaning of the criminal standard of proof ('beyond reasonable doubt') must be explained to them. This approach is pragmatic, in Posner's sense, and would seem to corroborate the proposal that the criminal trial is in Rawls' terminology, an arena for pure procedural justice.

This proposal is undoubtedly problematic. Several kinds of difficult question may be identified. First, if procedure is not to be evaluated against transcendental criteria, how are we to tell good from bad procedure? If procedural fairness is all there is then there seem to be no guidelines for evaluation of particular regimes. To put it starkly, what would be wrong with tossing a coin to decide the outcome of a criminal trial? Second, if procedure is the only matter for legal interest, what happens to the notion of miscarriage of justice as if (starkly again) a convicted murderer's victim turned out not to be deceased after all? If correct procedure was followed, should the conviction (and appropriate sentence) not stand?

The answers to these criticisms of pure proceduralism in criminal justice are interrelated. The central issue in pure procedure, as described by Rawls, is that the method has been knowingly agreed to by the relevant participants ahead of the implementation of the procedure in a particular case. Tossing a coin would be unlikely to be accepted by all relevant participants in a western (or indeed eastern) court of law, given that court processes are embedded in a complex tissue of sociocultural practices including apprenticeship and reporting. But tossing a coin is not in itself a bad procedure. For crimes where detection and bringing to trial are inherently probabilistic (such as vehicle speeding/drinking offences), it might not be entirely inappropriate. It would be less unfair than the uncontrolled happenstance of drawing a savage rather than a lenient magistrate. ${ }^{39}$ Another comment that might be made on stochastic procedure is that the happenstance of birth (rich or poor; 'indigenous' or not) has often been entirely acceptable to communities as the basis for differential

\footnotetext{
${ }^{38}$ Posner, above n 34, 44. Also see Edney, above n 34: a somewhat harsher view than Edney's of the relationship of law to literature is being proposed in the present paper.

${ }^{39}$ Tom Campbell has commented that 'One does not have to be a retributivist to be disturbed by the analogy between criminal law and a lottery': Campbell, above n 4, 148; yet it is sometimes through disturbing analogies that innovative ideas emerge.
} 
treatment such that the replacement of a nepotistic regime with a meritocratic regime calls forth the cry 'That's not fair.' 40

The issue of miscarriage of justice suggests an external criterion against which to measure procedure in a given case. Yet for a supposed corpse to come back to life (so that murder cannot have been done as found in a conviction) raises issues no different in principle to issues raised by confessions. At first blush, a confession may seem to cut through the procedural dimension, perhaps confirming or contradicting the procedural outcome but most significantly, obviating procedure: as it were, 'Go direct to Jail: Do not pass Go.' Students of the law of evidence soon however come to recognize the naivety of that approach: the law of confessions is fraught with the difficulties caused by induced confessions, confessions obtained as a result of breaches of an arrested person's rights and so on. ${ }^{41}$ The effect of confession is governed by procedure. Similarly, for a murder victim to come back to life, or to reappear having been presumed dead - as in Conan Doyle's The Norwood Builder - would not of itself challenge a conviction. Only through procedure (is this alive person really the same as the person presumed dead? Might he be an impostor or a clone?) will the earlier result be overturned. Similarly, 'perverting the course of justice' is a procedural matter. ${ }^{42}$ However dramatic, real-life events will only have a legal effect to the extent they are appropriated by a legal process.

Clearing away the Rawlsian presupposition of 'imperfect procedural justice' as the paradigm of criminal law would at least clarify the problems. Justice as pure procedure turns out to be a powerful idea. Posner has cautioned us that pragmatism 'has no soul' and the recognition that justice is mundane, even banal, is likewise something of a come-down. The law does the best it can: what more could it hope to do?

\footnotetext{
${ }^{40}$ Stanley Fish, 'Introduction: "That's not fair'” in Stanley Fish, There's No Such Thing as Free Speech And It's a Good Thing Too (1994) 3.

${ }^{41}$ Richard Mahoney, 'Abolition of New Zealand's Prima Facie Exclusionary Rule' [2003] Criminal Law Review 607, 608; Roderick Munday, 'Adverse Denial and Purposive Confession' [2003] Criminal Law Review 850.

${ }^{42}$ Susan Edwards, 'Perjury and Perverting the Course of Justice' [2003] Criminal Law Review 525.
} 